\title{
ANALISIS FAKTOR-FAKTOR DOMINANMANAJEMEN RISIKO TERHADAP KINERJA KEUANGAN PROYEK TAHAP KONSTRUKSI
}

\author{
Rinto Sugiharto \\ Program Magister Teknik Sipil Fakultas Teknik Sipil dan Perencanaan Universitas Trisakti \\ Jl. Kyai Tapa No. 1, Jakarta 11440 Telp 0215663232 pes. 8201 \\ Email: rintosugiharto08234@yahoo.co.id
}

\begin{abstract}
ABSTRAK
Dalam setiap aktivitas proyek tentu mengandung unsur risiko, semakin komplek sebuah proyek semakin besar risiko yang akan terjadi. Kurangnya perhatian terhadap manajemen risiko dapat mengakibatkan terganggunya proses komersial proyek. Risiko-risiko yang terjadi akan sangat berhubungan erat dengan penambahan biaya proyek, sehingga jika pengelolaan risiko tidak tepat maka akan mengakibatkan penambahan biaya proyek. Pada akhirnya akan mengurangi laba hingga kerugian proyek. Untuk itu diperlukan perencanaan dan respon yang tepat di awal perencanaan proyek. Penelitian ini bertujuan untuk mengidentifikasi faktor-faktor risiko dominan dalam pelaksanaan manajemen risiko tahap konstruksi, dan menganalisis serta mendapatkan faktor-faktor risiko dominan manajemen risiko terhadap kinerja keuangan proyek tahap konstruksi. Teknik pengumpulan data dengan mengunakan kuisioner dan telaah dokumen hasil penelitian sebelumnya. Kuesioner disebarkan kepada responden Manager proyek pada proyek-proyek Gedung sebanyak 40 responden. Metode yang digunakan adalah metode kuantitatif dan deskriptif. Dari hasil pengolahan dengan menggunakan metode Indeks Mean Risk Relative Importance (RRI). Analisa dilakukan dengan perangkat lunak SPSS. Didapatkan faktor-faktor risiko dominan pencapaian laba dengan persentase 5\%-10\% diantaranya adalah kesalahan estimasi harga dasar, sistem pengendalian biaya yang lemah, pembengkakan harga material dan peralatan, pembayaran berlangsung dalam waktu lama (collection periods) dan produktivitas tidak sesuai schedule pekerjaan. Respon terhadap pengelolaan risiko tersebut adalah dengan menghindari dan memitigasi risiko. Perencanaan risiko wajib dilakukan sebelum memulai proyek dengan tujuan akhir agar kinerja keuangan dapat berjalan baik dan pencapaian laba dapat sesuai target.
\end{abstract}

Kata Kunci: manajemen risiko, respon risiko, kinerja keuangan, komersial proyek, factor-faktor dominan manajemen risiko, mitigasi risiko, RRI

\section{ABSTRACT}

There is an element of risk in every project activity. The more complex a project is, the greater the risk that will occur. Lack of attention to risk management can lead to disruption of the commercial processes of the project. The risks that occur will be closely related to the additional cost of the project. If there is no appropriate risk management, it will result in additional project costs which in turn will potentially reduce the overall profit of the project. Therefore, proper planning and response are required at the beginning of project planning. This study aims to identify the dominant risk factors in the implementation of risk management in the construction phase and to analyze and obtain the dominant factors of risk management on the financial performance of a project construction phase. The data collection techniques used were questionnaires and review of previous research documents. The questionnaire was distributed to 40 project manager respondents in several building projects. This study uses quantitative and descriptive analysis methods. In addition, SPSS software is used to analyze the questionnaire results by using Mean Risk Relative Importance (RRI) Index. According to the analysis, it is found that the dominant risk factors for profit achievement with a percentage of 5\%-10\% include errors in estimating the base price, weak cost control systems, swelling prices for materials and equipment, long payment time (collection period) and productivity that does not match the work schedule. The response to manage the risks is to avoid and mitigate risks. A robust risk 
planning process must be carried out before the project starts, this is to ensure that the project can have a good financial performance and achieve profit targets.

Keyword: risk management, risk response, financial performance, project commercial, dominant risk management factors, risk mitigation, RRI

\section{PENDAHULUAN}

Aktivitas konstruksi bersifat kompleks dan melibatkan banyak sumber daya pekerja, peralatan dan material. Definisi proyek merupakan suatu usaha atau kegiatan bersifat sementara dan menghasilkan hasil berupa produk atau jasa yang bersifat khas atau khusus, dibatasi oleh waktu dan sumber daya. Pekerjaan proyek dilaksanakan untuk memenuhi target dengan menghasilkan suatu produk (deliverable). Hasil (deliverable) didefinisikan sebagai produk yang bersifat khas atau khusus, hasil, atau kemampuan untuk melakukan jasa yang diperlukan untuk dihasilkan dalam menyelesaikan proses, proyek, atau fasenya. Hasil (deliverable) bisa berwujud atau tidak berwujud. (PMBOK Edisi Ke-6, 2017)

Dalam setiap aktivitas tentu mengandung unsur risiko, semakin besar nilai proyek semakin besar pula risiko. Kejadian yang tidak pasti, bisa mengakibatkan keuntungan/peluang atau merugikan proyek atau risiko. Hal ini disampaikan oleh Wideman (1992), ketidakpastian yang kemungkinan menguntungkan disebut peluang (opportunity), sedangkan ketidakpastian yang mengakibatkan kerugian disebut risiko (risk).

Tujuan dilakukan penelitian ini adalah untuk mengidentifikasi, menganalisis dan mendapatkan faktor-faktor risiko dominan manajemen risiko terhadap kinerja keuangan proyek tahap konstruksi. Sedangkan manfaat penelitian yaitu untuk memberikan masukan bagi proyek-proyek konstruksi dalam upaya mengoptimalkan pelaksanaan dan pengendalian Manajemen Risiko Proyek sehingga bisa terlaksana dengan lebih efektif.

\section{A. Konsep Utama Untuk Manajemen Risiko}

Semua proyek berisiko karena proyek adalah usaha yang unik dengan berbagai tingkat kompleksitas yang bertujuan untuk memberikan manfaat. Hal ini juga dikarenakan proyek mempunyai batasan dan asumsi selain itu proyek harus menanggapi harapan pemangku kepentingan yang mungkin saling bertentangan dan berubah. Organisasi harus memilih untuk mengambil risiko proyek dengan cara yang dapat dikendalikan dan secara sengaja untuk menciptakan nilai sambil menyeimbangkan antara risiko dan imbalan.

Menurut Gunawan Logawa (2006) Manajemen Risiko dapat dimaksudkan sebagai proses dalam mengukur dan mengendalikan risiko yang sangat mungkin akan terjadi terhadap asset atau pendapatan dari suatu usaha.

Manajemen risiko proyek bertujuan untuk mengidentifikasi dan mengelola risiko yang tidak ditangani oleh proses manajemen proyek iainnya. Ketika tidak dikelola, risiko ini memiliki potensi menyebabkan proyek menyimpang dari rencana dan gagal untuk mencapai sasaran proyek yang telah ditetapkan. Akibatnya, efektivitas manajemen risiko proyek secara langsung berkaitan dengan keberhasilan proyek.

Dalam setiap proyek, ada dua tingkat risiko. Setiap proyek mempunyai risiko individual yang dapat memengaruhi pencapaian sasaran proyek. Sangat penting untuk mempertimbangkan tingkat risiko proyek secara keseluruhan, yang muncul dari kombinasi risiko individual dan sumber ketidakpastian proyek. Proses manajemen risiko proyek mengatasi kedua tingkat risiko dalam proyek-proyek, dan hal ini didefinisikan sebagai berikut:

Risiko-risiko individual proyek adalah merupakan kondisi yang tidak pasti, ketidakpastian yang jika terjadi, memiliki dampak positif atau negatif pada satu atau lebih sasaran proyek kontruksi.

Risiko-risiko proyek adalah dampak dari ketidakpastian pada proyek secara Sebagian dan keseluruhan, yang timbul dari semua sumber ketidakpastian termasuk risiko individual, mewakili keinginan stake holder atau pemangku kepentingan terhadap implikasi dari variasi dalam hasil proyek, baik positif maupun negative terhadap proyek. 
Dalam pelaksanaan proyek risiko individual proyek saat terjadi akan berdampak positif ataupun negatif terhadap sasaran proyek konstruksi. Dalam hal ini manajemen risiko proyek bertujuan untuk mengeksploitasi atau meningkatkan risiko positif (peluang) dan mengurangi atau menghindari dan mengelola risiko negatif (ancaman). Ancaman yang tidak dikelola dapat mengakibatkan isu atau masalah-masalah seperti keterlambatan, kelebihan biaya, kinerja yang kurang, atau kehilangan reputasi. Peluang yang ditangkap dapat memberikan manfaat seperti mengurangi waktu dan biaya, meningkatkan kinerja, atau reputasi.

Risiko proyek secara keseluruhan bisa positif ataupun negatif, manajemen risiko proyek secara keseluruhan bertujuan untuk menjaga eksposur risiko proyek dalam rentang yang dapat diterima dengan mengurangi pendorong variasi negatif, mempromosikan pendorong variasi positif, dan memaksimalkan probabilitas tercapainya sasaran proyek secara keseluruhan.

Risiko akan terus muncul selama masa proyek, sehingga proses manajemen risiko proyek harus dilakukan secara berulang. Risiko awalnya ditangani selama perencanaan proyek dengan menyusun strategi proyek. Risiko juga harus dipantau dan dikelola selama proyek berlangsung untuk memastikan bahwa proyek tetap pada jalurnya dan risiko yang tidak diharapkan (emergent risk) dapat ditangani,

Dalam rangka untuk mengelola risiko secara efektif pada proyek, tim proyek perlu tahu apa tingkat eksposur risiko yang dapat diterima dalam mencapai sasaran proyek. Hal ini didefinisikan dengan batas risiko (risk treshold) yang terukur yang mencerminkan selera risiko (risk appetite) suatu organisasi dan pemangku kepentingan proyek. Ambang batas risiko menggambarkan tingkat variasi yang dapat diterima di sekitar sasaran proyek. Batas risiko ini secara eksplisit dinyatakan dan dikomunikasikan kepada tim proyek dan tercermin dalam definisi tingkat dampak risiko untuk proyek tersebut.

Dalam rangka untuk mengelola risiko secara efektif pada proyek, tim proyek perlu tahu apa tingkat eksposur risiko yang dapat diterima dalam mencapai sasaran proyek. Hal ini didefinisikan dengan batas risiko (risk treshold) yang terukur yang mencerminkan selera risiko (risk appetite) suatu organisasi dan pemangku kepentingan proyek. Ambang batas risiko menggambarkan tingkat variasi yang dapat diterima di sekitar sasaran proyek. Batas risiko ini secara eksplisit dinyatakan dan dikomunikasikan kepada tim proyek dan tercermin dalam definisi tingkat dampak risiko untuk proyek tersebut.

\section{B. Kinerja Keuangan Proyek}

Mengutip pernyataan Duha, 2016, "definisi kinerja adalah merupakan cara atau kemampuan individu dalam bekerja untuk dapat memberikan hasil yang memuaskan ditempatnya bekerja dalam satu paket atau bagian pekerjaan tertentu atau pada suatu periode waktu tertentu yang ditentukan." Sementara merujuk Yuwono, 2007, "kinerja keuangan dapat di ukur dan pengukuran kinerja keuangan merupakan adalah tindakan pengukuran yang dilakukan terhadap berbagai aktivitas dalam rantai nilai yang ada pada proyek dan bisa diimplematasikan pada suatu proyek konstruksi."

Dalam suatu aktivitas bisnis deperlukan laporan keuangan yang akurat, yang merupakan suatu laporan sangat penting yang digunakan untuk memperoleh informasi sehubungan dengan posisi keuangan dan hasilhasil yang telah dicapai oleh perusahaan yang bersangkutan. Menurut Sutrisno, 2003, "menyatakan bahwa laporan keuangan proyek merupakan hasil dari proses akuntansi yang meliputi dua laporan utama yakni, neraca dan laporan laba rugi proyek konstruksi. Laporan keuangan akan dianggap sebagai laporan hasil kerja perusahaan bagi investor dan stake holder. Penyajian waktu laporan keuangan dibuat satu periode tutup buku, yaitu selama satu tahun waktu berjalan."

Dalam suatu proyek terdapat waktu penagihan atau collection periods. Sebagaimana pendapat Rangkuti, 2011, "bahwa collection periods digunakan untuk mengidentifikasi rata-rata waktu (hari) penjualan yang 
terikat pada piutang atau berapa lama waktu yang dipakai suatu proyek untuk mengumpulkan hasil penjualan setelah menjual produk yang dihasilkannya selama periode tertentu."

\section{METODE PENELITIAN}

Untuk mendapatkan hasil penelitian yang akurat maka diperlukan suatu metode yang tepat dan pada penelitian ini penulis menggunakan metode penelitian kuantitatif. Pertimbangan menggunakan meode ini karena terdapat unsur-unsur yang jelas dalam penelitian, seperti faktotor-faktor atau variabel-variabel yang akan dicari pada penelitian kali ini. Semua faktor-faktor atau variabel-variable penelitian merupakan hasil dari proses kajian literatur baik jurnal atau buku. Langkah pertama penelitian, peneliti akan menetapkan factor-faktor yang akan dipakai untuk mencapai tujuan dan sasaran pada penelitian ini. Faktor-faktor atau variabel-variabel tadi menjadi dasar digunakannya pendekatan penelitian. Menurut Creswell, 2002, perlu diketahui penelitian dengan pendekatan kuantitatif adalah penelitian ilmiah yang sistematis terhadap bagianbagian dari fenomena serta melihat hubungan-hubungan yang terjadi didalam penelitian tersebut. Penelitian kuatitatif menggunakan data yang bersifat terukur dalam angka. Manfaat utama metode kuantitatif adalah digunakan untuk menggenalisir data (generalizebility), kemudian dapat memprediksi data (prediction), dan mendeskripsikan hubungan sebab akibat (causal explanation) suatu obyek penelitian.

\section{DATA PENELITIAN}

Data yang akan digunakan dalam penelitian kali ini adalah data kuantitatif berskala nominal dan ordinal. Data diperoleh secara primer yakni dengan pengambilan langsung dari responden menggunakan alat bantu. Pengumpulan data dilakukan untuk memperoleh beragam informasi yang akan dianalisis dan digunakan untuk mencapai tujuan penelitian. Agar informasi yang hendak diperoleh bisa didapatkan dan tepat sesuai kebutuhan maka metode pengumpulan data harus benar. Terdapat dua jenis data yang hendak diperoleh dalam penelitian ini yakni data primer dan data sekunder. Data primer adalah data yang diperoleh langsung dari objek penelitian di lapangan berdasarkan pengamatan atau informasi langsung dari sumber yang dilakukan oleh peneliti, sedangkan data sekunder adalah data yang diperoleh secara tidak langsung dari pihak lain yang mengumpulkan atau memiliki data tersebut sebelumnya seperti instansi atau organisasi dan sebagainya. Dari hasil identifikasi penelitian sebelumnya diperoleh variabel-variable faktor-faktor dominan yang akan menjadi data penelitian seperti dalam tabel 1 dibawah ini :

Tabel 1 Variabel-variable Penelitian

\begin{tabular}{|c|c|c|c|}
\hline No & Kategori Risiko & & $\begin{array}{c}\text { Peristiwa Risiko } \\
\text { Variabel-variable Penelitian }\end{array}$ \\
\hline \multirow[t]{5}{*}{1} & $\begin{array}{l}\text { Risiko Manajemen } \\
\text { Konstruksi }\end{array}$ & A1 & $\begin{array}{l}\text { Terjadinya dokumen lelang tidak lengkap dan } \\
\text { tidak lengkap dan kurang jelas }\end{array}$ \\
\hline & & A2 & $\begin{array}{l}\text { Permintaan lapangan atas rencana kerja dari } \\
\text { pemilik yang sering berubah-ubah dari kontrak }\end{array}$ \\
\hline & & A3 & $\begin{array}{l}\text { Pengajuan dan permintaan perubahan atas } \\
\text { pekerjaaan yang telah selesai dari pemilik } \\
\text { proyek }\end{array}$ \\
\hline & & A4 & $\begin{array}{l}\text { Adanya permintaan perubahan desain/detail } \\
\text { pekerjaan pada waktu pelaksanaan sedang } \\
\text { berjalan }\end{array}$ \\
\hline & & A5 & Tidak diterimanya pekerjaan oleh Owner \\
\hline \multirow[t]{2}{*}{2} & Risiko Terlambatnya Proyek & B1 & $\begin{array}{l}\text { Kurang tersedianya perencanaan waktu/schedule } \\
\text { aktifitas dan sumber daya lengkap }\end{array}$ \\
\hline & & B2 & $\begin{array}{l}\text { Rencana urutan kerja yang tidak sama dan sering } \\
\text { berubah - ubah }\end{array}$ \\
\hline
\end{tabular}




\begin{tabular}{|c|c|c|c|}
\hline & & B3 & Pengadaan tenaga kerja tidak sesuai schedule \\
\hline & & B4 & $\begin{array}{l}\text { Pengadaan alat kerja dan material tidak sesuai } \\
\text { schedule }\end{array}$ \\
\hline & & B5 & Produktivitas tidak sesuai schedule pekerjaan \\
\hline \multirow[t]{8}{*}{3} & $\begin{array}{l}\text { Risiko Biaya dan Keuangan } \\
\text { Proyek }\end{array}$ & C1 & Kesalahan estimasi harga dasar \\
\hline & & $\mathrm{C} 2$ & Pembengkakan harga material dan peralatan \\
\hline & & $\mathrm{C} 3$ & $\begin{array}{l}\text { Pembayaran berlangsung dalam waktu lama } \\
\text { (Collection Periode) }\end{array}$ \\
\hline & & $\mathrm{C} 4$ & $\begin{array}{l}\text { Kenaikan harga yang tidak di cover dalam } \\
\text { kontrak }\end{array}$ \\
\hline & & $\mathrm{C} 5$ & Terjadi waste yang melebihi perkiraan \\
\hline & & C6 & Sistem pengendalian biaya yang lemah \\
\hline & & $\mathrm{C} 7$ & Kenaikan Bunga Bank \\
\hline & & $\mathrm{C} 8$ & Denda pajak \\
\hline \multirow[t]{6}{*}{4} & Risiko ketidakpastian pekerja & $\overline{\mathrm{D} 1}$ & Kurangnya kedisiplinan tenaga kerja \\
\hline & & D2 & Kurangnya jumlah tenaga kerja \\
\hline & & D3 & Kecelakaan tenaga kerja \\
\hline & & $\mathrm{D} 4$ & $\begin{array}{l}\text { Kurangnya keterampilan dan keahlian tenaga } \\
\text { Kerja }\end{array}$ \\
\hline & & $\overline{\mathrm{D} 5}$ & Produktivitas pekerja yang rendah \\
\hline & & D6 & Pemogokan tenaga kerja \\
\hline \multirow[t]{5}{*}{5} & $\begin{array}{l}\text { Risiko ketidakpastian } \\
\text { material dan peralatan }\end{array}$ & E1 & Material ditolak/direject \\
\hline & & E2 & Keterlambatan Pengiriman material dan alat \\
\hline & & E3 & Keterlambatan pembayaran material dan alat \\
\hline & & $\mathrm{E} 4$ & $\begin{array}{l}\text { Perubahan spesifikasi material pada pertengahan } \\
\text { proyek }\end{array}$ \\
\hline & & E5 & Peningkatan jumlah material \\
\hline
\end{tabular}

Variable-variable penelitian berjumlah 29 (dua puluh Sembilan) yang terdiri dari 5 kategori dan akan di analisis untuk mengetahui faktor-faktor dominan.

\section{PENGUMPULAN DATA PENELITIAN}

Dibutuhkan data yang akurat dalam penelitian ini, baik data primer dan sekunder. Hal pertama yang dilakukan adalah metode pengumpulan data primer dengan melakukan pemantauan lapangan dan penyebaran

J-TESLINK @ 2020 
angket atau kuisioner, sementara untuk data sekunder menggunakan metode telaah dokumen. Berikut ini penjelasan dari tiap metode:

- Kuisioner

Penyebaran kuisioner merupakan suatu teknik pengumpulan informasi yang memungkinkan peneliti mempelajari sikap-sikap, keyakinan, perilaku, dan karakteristik beberapa orang dalam suatu kelompok, yang dilakukan dengan mengajukan serangkaian pertanyaan yang disusun sistematis dalam sebuah formulir isian (Narbuko \& Achmadi, 2007). Penerapan responden kuesioner dilakukan dengan menggunakan teknik sampling. Teknik kuesioner digunakan untuk mengumpulkan data terkait persepsi manager proyek.

- Telaah Dokumen

Telaah dokumen adalah metode pengumpulan data sekunder yang dilakukan dengan cara mencari dokumen terkait sasaran penelitian yang hendak dicapai. Dokumen-dokumen yang dijadikan sumber informasi bisa berupa dokumen peraturan-peraturan, dokumen hasil kompilasi data yang diterbitkan oleh lembaga tertentu maupun sumber-sumber lain yang terkait dengan penelitian seperti sumber informasi dari media massa maupun internet.

- Responden Penelitian

Populasi merupakan wilayah generalisasi yang terdiri atas objek atau subjek dengan karakteristik tertentu yang ditetapkan oleh peneliti untuk dipelajari dan kemudian ditarik kesimpulannya (Sugiyoono, 2016). Penentuan target populasi didasarkan pada tujuan penelitian yang sudah ditetapkan. Target populasi dari penelitian adalah Project Manager, Site Operasional Project, Site Engineering Project, Site Admistration Project, yang berjumlah 40 orang.

\section{- Penentuan Kuisioner}

Penelitian yang akan dilaksanakan ini harus menggunakan metode yang tepat, metode penelitian yang dilakukan adalah menggunakan kuesioner dengan pendekatan skala likert dan responden diminta untuk menjawab pertanyaan yang tersedia berdasarkan penilaian responden. Menurut Sugiyono (2016), skala likert digunakan untuk mengukur sikap, pendapat, dan persepsi seseorang atau sekelompok orang tentang fenomena sosial. Pada penelitian kuantitatif ini, responden diminta untuk menjawab dengan memberikan tanda silang $(\mathrm{X})$ pada kolom yang paling mewakili pendapat responden.

\section{ANALISA DATA}

Pemilihan metode analisa yang tepat adalah sangat penting untuk mengidentifikasi faktor-faktor atau variabel-variabel penelitian yang relevan sehingga akan didapatkan hasil penelitian sesuai dengan tujuan penelitian. Data-data hasil kuisioner dari responden merupakan input untuk melakukan analisa data. Tahapan selanjutnya setelah data-data terkumpul, maka data disusun dengan baik sesuai tujuan. Proses analisa akan dilakukan menggunakan perangkat lunak SPSS (Statistical Program fo Sosial Science). Untuk memperoleh data Index Mean Risk Relative Importance (RRI) dan peringkat atau rangking risiko dominan. Penetapan peringkat atau rangking risiko-risiko dominan merupakan langkah selanjutnya dalam mencapai tujuan akhir penelitian ini. Pengurutan peringkat risiko dimaksudnkan untuk mengetahui faktor-fakto atau variablevariabel risiko mana saja yang akan menjadi peringkat pertama yang mendapat perhatian dari responden dan akan menjadi skala prioritas pengelolaan risiko. Penentuan peringkat ditentukan dengan mengurutka variable-variabel risiko dengan index mean RRI tertinggi menuju terendah. Selain itu peringkat risiko merupakan hasil perkalian nilai dampak dengan frekuensi di dapat nilai risiko kemudian terhadap nilai risiko dilakukan rangking risiko.

\section{Analisis Statistik Non Parametrik}

Analisa perhitunan selanjutnya digunakan analisis statistik non parametrik dengan menggunakan analisa kuantitatif. Analisa ini bergantung pada probabilitas risiko dan dampak penilaian dari responden penelitian. 
Besaran nilai rata-rata atau mean yang ditunjukkan untuk mendapatkan gambaran secara kuantitatif mengenai faktor-faktor risiko dalam manajemen risiko adalah hasil yang akan diperoleh dari penilaian probabilitas dan dampak risiko.

Data yang dikumpul dari survei kuesioner menggunakan diolah dengan program SPSS. Penentuan peringkat risiko adalah langkah selanjutnya yang akan dilakukan untuk mencapai tujuan penelitian.

\section{Analisis Statistik Deskriptif}

Selanjutnya dilakukan analisis statistik deskriptif merupakan metode statistik yang berkenan dengan pengumpulan dan peringkasan data penelitian serta penyajian hasil penelitian dengan peringkasan tersebut dengan cara mendeskripsikan atau menggambarkan data yang diperoleh sebagaimana adanya tanpa bermaksud membuat kesimpulan yang berlaku untuk umum atau generalisasi. Metode penelitian yang dilakukan pada populasi (dengan tanpa diambil sampel) pasti akan menggunkan statistik deskriptif dalam analisa hasil datanya. Namun jika penelitian dilakukan pada sampel suatu ppopulasi, maka analisanya dapat menggunakan statistk deskriptif maupun secara inferensial.

Fokus teknik analisis statistik pada penelitian adalah untuk menjelaskan hubungan/kaitan antara beberapa variabel-varibel penelitian. Penyajian data pembahasan diutamakan pada cara membaca dan menafsirkan arti dari parameter-parameter yang diperoleh dari hasil pengolahan data yang terdapat pada output SPSS dari hasil kuisioner responden.

Terdapat 5 (lima) kelas skala Mean dengan range yang sama, maka ukuran skala di interpretasikan pada tabel 3.2 dibawah ini, sebagai berikut :

Tabel 3.2 Daftar Nilai Mean

\begin{tabular}{|l|l|l|}
\hline No. & \multicolumn{1}{|c|}{ Nilai Mean } & \multicolumn{1}{|c|}{ Keterangan } \\
\hline 1. & $1.00-1.79$ & Sangat kurang baik \\
\hline 2. & $1.80-2.59$ & Kurang baik \\
\hline 3. & $2.60-3.39$ & Cukup baik \\
\hline 4. & $3.40-4.19$ & Baik \\
\hline 5. & $4.20-5.00$ & Sangat baik \\
\hline
\end{tabular}

Sumber : R. Bryan 2015

Analisis statistik deskriptif dalam penelitian ini menggunakan analisa kuantitatif yang bergantung pada probabilitas risiko dan dampak penilaian. Hasil yang diperoleh dari penilaian probabilitas dan dampak risiko adalah nilai rata-rata atau mean yang ditunjukkan untuk mendapatkan gambaran secara kuantitatif mengenai Risk Relative Importance (RRI). Data yang dikumpul dari survei kuesioner menggunakan program SPSS. Rangking risiko merupakan langkah selanjutnya dalam mencapai tujuan penelitian ini dilakukan. Rangking risiko bertujuan untuk mengetahui variabel risiko mana yang menjadi peringkat pertama yang mendapat perhatian dari responden. Rangking risiko dapat ditentukan cukup dengan mengurutkan variabel risiko dengan indeks mean RRI tertinggi akan menduduki rangking atau peringkat pertama hingga variabel risiko yang memiliki indeks rata-rata atau mean RRI terendah akan menduduki rangking atau peringkat terakhir. (Rusdi, Suharman, Imam 2011). 


\section{Uji Validitas}

Dalam pengolahan data diperlukan validitas data yaitu ketepatan atau kecermatan suatu instrument dalam mengukur apa yang diukur dalam suatu penelitian. Tujuan dari uji validitas adalah untuk mengukur ketepatan suatu item kuesioner. Untuk menilai apakah item-item pada kuesioner tersebut sudah tepat dalam mengukur apa yang ingin diukur atau masih kurang tepat. Nilai uji validitas item kuisioner ditunjukan dengan adanya korelasi atau dukungan terhadap item kuisioner total (skor total). Cara melakukan perhitungan dilakukan dengan mengkorelasikan antara skor item-item kuisioner dengan skor total item-item kuisioner. Dari hasil perhitungan korelasi item-item kuisioner akan didapat suatu koefesien korelasi yang akan digunakan untuk mengukur nilai validitas suatu item kuisioner dan untuk menentukan suatu item kuisioner layak digunakan atau tidak layak digunakan. Diperlukan perhitungan uji signifikasi untuk menentukan layak atau tidaknya suatu item yang akan digunakan koefisien korelasi pada taraf siginifikasi sebesar 0.05 . Hasil analisa suatu item kuisioner dianggap valid jika berkorelasi signifikan terhadap skor total atau jika melakukan penilaian langsung terhadap koefisien korelasi bisa digunakan degan batas nilai minimal korelasi adalah sebesar 0.30 koefisien korelasinya.

Keputusan Uji:

Pertama, data penelitian valid jika nilai $r$ hitung > $r$ tabel, maka Ho ditolak.

Kedua, data penelitian tidak valid jika nilai $r$ hitung $<r$ tabel, maka Ho diterima.

\section{Uji Reliabilitas}

Suatu penelitian membutuhkan data yang handal, untuk itu dilakukan uji reliabilitas merupakan alat untuk mengukur suatu kuesioner yang merupakan suatu indikator dari peubah atau konstruk dari data penelitian. Jawaban responden terhadap pernyataan kuisioner diharapkan konsisten atau stabil dari waktu ke waktu dari suatu rangkaian kuisioner atau reliable atau handal. Nilai reliabilitas suatu uji merujuk pada derajat konsistensi, stabilitas, daya prediksi dan akurasi kuisioner. Hasil Pengukuran yang memiliki nilai reliabilitas yang tinggi adalah pengukuran yang dapat menghasilkan data yang realiable atau handal.

Nilai reliabilitas merupakan suatu indeks yang menunjukkan sejauh mana suatu alat ukur dapat diandalkan dalam suatu kuisioner penelitian (Masri Singarimbun). Data hasil kuisioner penelitian bersifat reliable, apabila suatu penelitian dipakai dua kali untuk mengukur gejala yang sama dan hasil pengukuran yang diperoleh relative konsisten atau sama handal. Atau dapat dikatakan, reliabilitas menunjukan konsistensi suatu alat pengukur didalam pengukur gejala yang sama pada suatu penelitian.

Nilai koefisien reliabilitas adalah nilai yang menunjukan tinggi rendahnya reliabilitas. Nilai koefisien reliabilitas yang tinggi ditunjukan dengan nilai $\mathrm{r}$ mendekati angka 1 . Nilai realiabilitas secara umum dianggap sudah cukup memuaskan jika $\geq 0.600$.

Adapun ukuran kemantapan alpha menurut Triton 2006, sebagai berikut:

- Pertama, data penelitian yang artinya tidak reliabel jika Alpha cronbach's 0,00 s.d. 0,20

- Kedua, data penelitian yang artinya kurang reliabel Alpha cronbach's 0,21 s.d. 0,40

- Ketiga, data penelitian yang artinya cukup reliabel jika Alpha cronbach's 0,41 s.d. 0,60

- Keempat, data penelitian yang artinya reliabel jika Alpha cronbach's 0,61 s.d. 0,80

- Kelima, data penelitian yang artinya sangat reliabel jika Alpha cronbach's 0,81 s.d. 1,00

\section{HASIL DAN PEMBAHASAN}

Analisis dan Pembahasan Index Mean RRI dilakukan terhadap terhadap data yang didapat dari kuisioner terhadap responden, sebagai berikut :

1. Faktor-Faktor Risiko Dominan Manajemen Risiko Proyek Pada Tahap Konstruksi terhadap Konsekuensi Penambahan Biaya 
Diperoleh bahwa faktor-faktor risiko dominan manajemen risiko proyek pada tahap konstruksi terhadap konsekuensi penambahan biaya, dengan peringkat 5 (besar), teridiri dari :

Tabel 2. Faktor-Faktor Risiko Dominan Manajemen Risiko Proyek Pada Tahap

Konstruksi terhadap Konsekuensi Penambahan Biaya

\begin{tabular}{|l|c|l|c|c|}
\hline No & & \multicolumn{1}{|c|}{ Faktor Risiko } & Total Index & $\begin{array}{c}\text { Persentase Konsekuensi } \\
\text { Penambahan Biaya }\end{array}$ \\
\hline 1. & C1 & Kesalahan estimasi harga dasar & 15,42 & $>5 \%-10 \%$ \\
\hline 2. & C6 & $\begin{array}{l}\text { Sistem pengendalian biaya yang } \\
\text { lemah }\end{array}$ & 15,13 & $>5 \%-10 \%$ \\
\hline 3. & C2 & $\begin{array}{l}\text { Pembengkakan harga material dan } \\
\text { peralatan }\end{array}$ & 14,74 & $>5 \%-10 \%$ \\
\hline 4. & C4 & $\begin{array}{l}\text { Kenaikan harga yang tidak di } \\
\text { cover dalam kontrak }\end{array}$ & 14,32 & $>5 \%-10 \%$ \\
\hline 5. & B5 & $\begin{array}{l}\text { Produktivitas tidak sesuai } \\
\text { schedule pekerjaan }\end{array}$ & 13,69 & $>5 \%-10 \%$ \\
\hline
\end{tabular}

Sumber Tabel : Hasil Olah Data SPSS 20

Memperhatikan data rangking bahwa faktor-faktor risiko yang paling dominan mempengaruhi penambahan biaya dalam pelaksanaan proyek tahap konstruksi adalah $\mathrm{C} 1$ yaitu kesalahan estimasi harga dasar. Dalam pelaksanaan manajemen risiko pada tahap konstruksi kesalahan estimasi harga dasar akan dapat mengakibatkan penambahan biaya yang besar yaitu antara 5\%-10\%.

2. Faktor-Faktor Risiko Dominan Manajemen Risiko Proyek Pada Tahap Konstruksi terhadap Konsekuensi

Pencapaian Laba

Memperhatikan data analisa diperoleh bahwa faktor-faktor risiko dominan manajemen risiko proyek pada tahap konstruksi terhadap konsekuensi pencapaian laba, dapat disajikan dalam 5 (lima) peringkat tertinggi, yang terdiri dari :

Tabel 3. Faktor-Faktor Risiko Dominan Manajemen Risiko Proyek Pada Tahap Konstruksi terhadap Konsekuensi Penambahan Biaya

\begin{tabular}{|l|l|l|c|c|}
\hline No & \multicolumn{1}{|c|}{ Faktor Risiko } & Total Index & $\begin{array}{c}\text { Persentase Konsekuensi } \\
\text { Pencapaian Laba }\end{array}$ \\
\hline 1. & C1 & Kesalahan estimasi harga dasar & 14,74 & $>5 \%-10 \%$ \\
\hline 2. & C6 & $\begin{array}{l}\text { Sistem pengendalian biaya yang } \\
\text { lemah }\end{array}$ & 14,17 & $>5 \%-10 \%$ \\
\hline 3. & C2 & $\begin{array}{l}\text { Pembengkakan harga material dan } \\
\text { peralatan }\end{array}$ & 14,17 & $>5 \%-10 \%$ \\
\hline 4. & C3 & $\begin{array}{l}\text { Pembayaran berlangsung dalam } \\
\text { waktu lama (Collection Periode) }\end{array}$ & 13,47 & $>5 \%-10 \%$ \\
\hline 5. & B5 & $\begin{array}{l}\text { Produktivitas tidak sesuai } \\
\text { schedule pekerjaan }\end{array}$ & 13,41 & $>5 \%-10 \%$ \\
\hline
\end{tabular}

Sumber Tabel : Hasil Olah Data SPSS 20

Uraian diatas memperlihatkan bahwa faktor-faktor risiko yang paling dominan mempengaruhi pencapaian laba dalam pelaksanaan proyek tahap konstruksi adalah $\mathrm{C} 1$ yaitu kesalahan estimasi harga dasar. Dalam pelaksanaan manajemen risiko pada tahap konstruksi kesalahan estimasi harga dasar akan dapat mengakibatkan pencapaian laba akan terkoreksi sebesar 5\%-10\%. 


\section{Respon terhadap Risiko Dominan Manajemen Risiko Proyek Pada Tahap Konstruksi}

Memperhatikan hasil oleh data berikut, akan menunjukan hasil analisis nilai mean faktor-faktor risiko dominan manajemen risiko proyek pada tahap konstruksi diperoleh peringkat respos terbesar terhadap konsekuensi pencapaian laba.

Tabel 4. Hasil Mean Respon Risiko Dominan Manajemen Risiko Proyek Pada Tahap Konstruksi

\begin{tabular}{|c|c|c|c|c|c|c|c|c|}
\hline \multirow[t]{2}{*}{ No } & \multirow[t]{2}{*}{ Faktor Risiko } & \multicolumn{5}{|c|}{ Penilaian } & \multirow{2}{*}{$\begin{array}{c}\text { Jawaban } \\
\text { Terbanyak }\end{array}$} & \multirow{2}{*}{$\begin{array}{c}\text { Persentase } \\
\text { Jawaban } \\
\text { Terbanyak }\end{array}$} \\
\hline & & 1 & 2 & 3 & 4 & 5 & & \\
\hline $\mathrm{C} 1$ & Kesalahan estimasi harga dasar & 7 & 9 & 8 & 4 & 12 & $\begin{array}{l}\text { Menhindari } \\
\text { Risiko }\end{array}$ & $30 \%$ \\
\hline C6 & $\begin{array}{l}\text { Sistem pengendalian biaya yang } \\
\text { lemah }\end{array}$ & 3 & 11 & 5 & 5 & 16 & $\begin{array}{l}\text { Menhindari } \\
\text { Risiko }\end{array}$ & $40 \%$ \\
\hline $\mathrm{C} 2$ & $\begin{array}{l}\text { Pembengkakan harga material } \\
\text { dan peralatan }\end{array}$ & 3 & 19 & 7 & 4 & 7 & $\begin{array}{c}\text { Mengurangi/ } \\
\text { Mitigasi } \\
\text { Risiko }\end{array}$ & $47,5 \%$ \\
\hline $\mathrm{C} 4$ & $\begin{array}{l}\text { Kenaikan harga yang tidak di } \\
\text { cover dalam kontrak }\end{array}$ & 8 & 10 & 8 & 4 & 10 & \begin{tabular}{|c|} 
Menhindari \\
Risiko dan \\
Mengurangi/ \\
Mitigasi \\
Risiko
\end{tabular} & $25 \%$ \\
\hline$\overline{\mathrm{B} 5}$ & $\begin{array}{l}\text { Produktivitas tidak sesuai } \\
\text { schedule pekerjaan }\end{array}$ & 3 & 22 & 8 & 1 & 6 & $\begin{array}{c}\text { Mengurangi/ } \\
\text { Mitigasi } \\
\text { Risiko }\end{array}$ & $55 \%$ \\
\hline
\end{tabular}

Sumber Tabel : Hasil Olah Data SPSS 20

Pada tabel diatas dapat dijelaskan bahwa Respon terhadap Risiko Dominan Manajemen Risiko Proyek C1 yaitu kesalahan estimasi harga dasar mayoritas responden menyatakan menghindari risiko tersebut. Untuk risiko C6 (sistem pengendalian biaya yang lemah) respon yang lakukan adalah menghindari risiko. Kemudian untuk faktor risiko C2 pembengkakan harga material dan peralatan respon yang dilakukan adalah mengurangi/mitigasi risiko. Respon terhadap risiko $\mathrm{C} 4$ (kenaikan harga yang tidak di cover dalam kontrak respon terbagi menjadi dua kelompok yaitu mereka memilih menghindari risiko dan mengurangi/mitigasi risiko. Untuk respon risiko B5 (produktivitas tidak sesuai schedule pekerjaan) respon yang dilakukan adalah mengurangi/mitigasi risiko tersebut.

\section{KESIMPULAN DAN SARAN}

\section{Kesimpulan}

Berdasarkan analisis data yang telah dilaksanakan, maka didapatkan bahwa faktor-faktor dominan manajemen risiko proyek pada tahap konstruksi yang dapat mempengaruhi kinerja keuangan dan mengurangi pencapaian laba, adalah :

1. Kesalahan estimasi harga dasar

2. Sistem pengendalian biaya yang lemah

3. Pembengkakan harga material dan peralatan

4. Pembayaran berlangsung dalam waktu lama (collection periods)

5. Produktivitas tidak sesuai schedule pekerjaan 
Jika tidak dikelola dengan baik maka factor-faktor risiko tersebut dapat mengurangi laba 5 sd $10 \%$ dari nilai rencana laba proyek. Perlu adanya respon yang baik dan tepat untuk mengelola faktor-faktor risiko di atas pada masa perencanaan proyek yaitu dengan cara menghindari dan memitigasi risiko agar komersial proyek dapat tercapai.

\section{Saran}

Dari hasil penelitian di atas, maka penulis menyarankan hal-hal sebagai berikut :

1. Hasil penelitian ini diharapkan untuk mempermudah dalam memberikan informasi mengenai risikorisiko dominan penyebab terjadinya penambahan biaya yang mempengaruhi kinerja keuangan proyek tahap konstruksi

2. Sebelum melaksanakan proyek, kontraktor hendaknya memperhatikan faktor-faktor risiko dominan tersebut diawal perencanaan proyek dan melakukan mitigasi yang baik agar komersial proyek dapat tercapai.

3. Untuk penelitian selanjutnya penulis menyarankan untuk dapat diteliti mengenai faktor-faktor risiko dominan berdasarkan Owner. Owner proyek dari pihak pemerintah dengan sumber dana dari APBN dengan owner swasta dengan dukungan dana dari pinjaman bank akan menarik sekali untuk dikaji pengaruhnya terhadap kinerja keuangan proyek.

\section{DAFTAR PUSTAKA}

Adriani Okta Fara Dita, Anik Ratnaningsih, Sri Sukmawati, 2017, Jurnal "Identifikasi Risiko Dominan Internal Non Teknis Yang Berdampak Pada Biaya Konstruksi High Rise Building Menggunakan Metode Severity Index”, Jurnal Rekayasa Sipil dan Lingkungan, ISSN 2548-9518 Vol. 01, No. 02, Juli 2017

Creswell, J. 2002. Educational research: Planning, conducting, and evaluating Quantitative and Qualitative research. Upper Saddle River, NJ: Merrill Prentice Hall.

Duffield, C \& Trigunarsyah, B. 1999. Project Management-Conception to Completion. Engineering Education Australia. (EEA). Australia.

Enma Mediawati Sebayang, 2018, Jurnal "Pengelolaan Risiko Proyek Gedung Bertingkat Pada PT. XYZ Di Jakarta terhadap Kinerja Waktu”, Jurnal ISSN 0853-2982 Vol. 25 No. 3, Desember 2018.

Ervianto, I.W. (2005). Manajemen Proyek Konstruksi Edisi Revisi. Yogyakarta. Andi.

Hendi Kurniawan, Ida Ayu Ari Anggraeni, 2020, Jurnal "Analisis Risiko Rantai Pasok Material Terhadap keterlambatan Pelaksanaan Proyek Konstruksi”, Jurnal REKAYASA SIPIL / Volume 14, No.1 - 2020 ISSN $1978-5658$

Kerzner, H, 2006, Project Management. A System Approach to Planning, Scheduling, and Controlling, 10th ed.John Wiley \& Sons, New York

Logawa, G, 2006, Bunga Rampai Manajemen Proyek Konstruksi, Penerbit Universitas Trisakti 2016,

Jakarta Leo J. Susilo, Vitor Riwu Kaho, 2018, Manajemen Risiko ISO 31000:2018, Grasindo, 2018, Jakarta

Narbuko dan Achmadi. 2007. Metodologi Penelitian. Jakarta: Bumi Aksara.

Project Manajemen Istitute, 2017, PMBOK® GUIDE, Pedoman Kerangka Ilmu Manajemen Proyek, Edisi

Keenam, Jakarta, 2017

Soeharto, I. 1999. Manajemen Proyek dari konseptual sampai operasional Jilid I, Edisi ke 2. Erlangga, Jakarta. Sugiyono, (2016). Metode Penelitian Kuantitatif Kualitatif dan R\&D. Bandung: UPI PRESS

Tjahjono, H.K., 2009, Metode Penelitian Bisnis 2.0, Edisi Pertama, Yogyakarta: Visi Solusi Madani.

Wideman, Max. R.1992. Project And Program Risk Management: A Guide To Managing Project Risk

Opportunities. Project Management Institute. Amerika. 